\title{
Correlation between Morality and Religion in Ukrainian Society: Productive Ideas in German Idealism for Modern Consideration
}

\author{
Vadym Tytarenko \\ PhD, Assistant Professor, Taras Shevchenko National University of Kyiv (Kyiv, Ukraine) \\ E-mail: tytarenko.vadym@gmail.com \\ ORCID: 0000-0001-9251-8859
}

Kant's and Hegel's ways to resolve the problem of correlation between the morality and religion at first glance seem to be opposite. Such opinion is evidenced by Hegel's statements in which he puts himself into the opposition to Kant and demonstrates his own theoretical and methodological superiority. Many scholars of German Idealism support such opinion. But in spite of such radical alternativeness, in author's opinion, it is possible to discover some mutual and non-contradicting positions of Kant and Hegel on the issue of correlation between the morality and religion.

The purpose of this article is a comparison of the Kant's and Hegel's ways to resolve the problem of correlation between the morality and religion in order to discover the moments of complementarity in these extremely alternative philosophical systems. The results of this inquiry can be fruitfully assembled and used by the modern Ukrainian political and social science for resolving of this problem within the modern Ukrainian society. To achieve this purpose, it is necessary: a) to analyze and compare the general methodology used by Kant and Hegel in their philosophical systems; b) to conduct a comparison of their doctrines on morality, religion, and their correlation; c) to carry out a research in order to discover how Kant's and Hegel's theoretical and practical models, as well as achieved conclusions, can be fruitfully applied in the modern comprehension of the problem of correlation between the morality and religion.

Key Words: Kant, Hegel, morality, religion, Ukraine, society, religious safety

Received March 28, 2018; accepted May 25, 2018

Ukrainian Policymaker, Volume 2, 2018: 41-47

DOI: $10.29202 / \mathrm{up} / 2 / 6$

\section{Introduction}

The inquiry on productive potential of Kant's and Hegel's ethics and philosophy of religion requires a general outline of the present state and comprehension of these phenomena in the context of individual and a social being.

The correlation between morality and religion can be comprehended both at the individual (subjective) level and at the level of social consciousness. On an individual level, it is possible

(C) Tytarenko, Vadym, 2018 
to provide a didactic connection between religion and moral consciousness. Such didactic connection appears as the potential ability of the religious education and upbringing to form and improve the level of morality (in the meaning of the sense of inner duty) of an individual. At the social level, such an individual-didactic function of religion becomes a certain general opportunity for the increase of the general moral standard of society. The main difficulty of the didactic role of religion in the matter of development of both individual and social morality appears as the lack of a definite, universally valid criterion of Good and Evil. In modern Ukrainian society, there is still no certainty about common values. This situation is caused by the peculiarities of the post-totalitarian condition of modern Ukraine. The society rejected the previous socialistic-utopia ideals and their related individual and social aspirations. Some important issues on Ukrainian post-totalitarian rehabilitation are outlined by Sergii Rudenko in his paper. [Tytarenko \& Rudenko, 2018]

In the new Ukrainian society religion is the extremely powerful force claiming to establish new ideals of moral perfection. Ukrainian society is currently experiencing an unprecedented surge of religiosity. The social aspiration to find moral benchmarks also explains the emergence and popularity of the latest non-orthodox religious communities that offer different ways of self-improvement. It's difficult not to get lost in such religious diversity. The individual must have a clear awareness of its own aspirations and be reflexive on all proposed ways of selfimprovement.

Along with a surge of religiosity, there is also a growing mercantile-utilitarian attitude towards social problems. In such situation, the morality descent appears as inevitable. The traditional issues and problems of individual improvement remain beyond the aspirations of utility. This attitude to the world can be combined with religiosity. However, such religiosity cannot be considered as true. The motive of such religiosity is the Fear of God, and its goal is to obtain a profit, etc. Such moral situation and pseudo-religiosity, unfortunately, are the realities of the modern Ukrainian society. Gennadii Aliaiev in his writing on the religion's impact on culture development proposes some significant explanations on this problem [Aliaiev, 2016, 190-198]. In order to resolve this difficult situation, as well as other problems of the formation and development of Ukrainian society, it is necessary to revise the most significant intellectual heritage of the past. On the problem of morality, religion and their correlation, the important achievements were gained by Immanuel Kant and Georg Wilhelm Friedrich Hegel.

\section{Kant's and Hegel's methodological solutions for the inquiry of the problem of correlation between the morality and religion}

One of the main reasons for the interpretation of Kant's and Hegel's doctrines as extremely alternative appears the methodology used by thinkers to resolve the basic philosophical problems. Let us overview and compare the methodology of both thinkers.

The first point of the Kantian approach to the consideration, analysis and solution of the problem of the correlation between morality and religion is an "aprioristic" interpretation of the human nature. "Aprioristic" approach appears as a peculiarity of his transcendental methodology. Kant states that the moral ability and the religious consciousness are the essential elements of human nature that are revealed by the study of the theoretical and practical application of the reason and the judgement.

The second crucial point is the proclamation of the duality of the world: the distinction between the "noumena" (the sphere of man's freedom (free causality) and the "phenomena" 
(the sphere of the inevitability of the law of causality). As a result of the interpretation of morality and religiosity as the pre-experiential abilities of the human soul (the noumenal component), Kant proclaims them to be the conditions of such social phenomena as law and religion (phenomenal correspondences). The thinker, on the pages of his Critiques [Kant, 1998; Kant, 2015] and numerous letters as well, repeatedly noted that the main purpose of his philosophical inquiry is to answer the question "what is a human being?" [Kant, 1977, 205]. Such question represents Kant's intention to conduct all his inquiries towards one purpose: to uncover the deep essentials of a human being by observation of their real-life manifestations: science, art, law, religion, etc. Due to such aims of his inquiry, Kant deliberately ignores the cultural-historical perspective of interpretation of mentioned phenomena in order to discover and explore all their conditions within the "human soul." Such consideration of human being and cultural-historical process essentially distinguishes Kant's and Hegel's approaches to solving the problem of the correlation between morality and religion.

Essential peculiarities of the Hegelian approach to the morality and religion correlation are "historism", the dialectical method and philosophical monism.

Unlike Kant, Hegel tries to build a chain of historical justifications for ability, reality or necessity of any phenomenon of history and culture. In his opinion, any randomness is random only at first glance. Historical research can prove the regularities that were previously not noticeable. One of the most important Hegelian philosophical discoveries is the total inconsistency of reality. Historical formation occurs due to constant struggle and interaction of contradictory elements.

The second peculiarity of Hegel's research strategy is the monist philosophical approach, which reveals itself in the idea of spiritual nature of reality. Such interpretation of reality appears as the reason why some authoritative scholars consider Hegel's system to be a "mystical pantheism." The Spirit acts as the essential background of the world. It unites in itself the whole reality. All historical processes appear as the specification of the general scheme of "self-movement," "selfrevelation"' of the "Absolute." This process, the thinker calls the Spirit's implementation of its own concept, the embodiment of the logical "Absolute Idea". Hegelian philosophical monism gives a possibility to conduct a philosophical inquiry in the field of objective historical processes, casting the individual, subjective level aside. Hegel carries out his studies of morality, religion, and their correlation in the field of objective history. Mentioned peculiarity shows a distinction between his theoretical position and the Kant's one.

\section{Kant and Hegel on the correlation between morality and religion}

Kant's heritage on ethics and philosophy of religion demonstrates the relative sustainability of his research principles and positions in this field. On the contrary, Hegel's philosophical creativity is extremely dynamic and changing. There are three more or less independent ways of Hegel's consideration of morality, religion and their correlation: a) in early theological writings, b) in "Phenomenology of Spirit", c) in the "Encyclopedia of Philosophical Sciences." Such variety of ideas and evaluations makes difficult to compare Kant's and Hegel's philosophical conclusions. Nevertheless, it is necessary to compare Kant's ethical doctrine with the above-mentioned variants of the Hegelian doctrine of morality and religion in order to make the corresponding theoretical generalizations.

Kant's philosophy played an important role in the formation of Hegel's philosophical position. The first philosophical steps that he carries on the pages of his early theological 
works bear the obvious imprint of the Kantian perspective and methodology. His first theoretical receptions of Kant's ideas took place in the field of ethics and philosophy of religion. Hegel's ethical views, presented in his early writings, such as Folk religion and Christianity [Hegel, 1907, 1-72], The Life of Jesus [Hegel, 1907, 73-136], Positivity of the Christian Religion [Hegel, 1907, 137-240], almost completely coincide with the moral doctrine of Immanuel Kant. Hegel's philosophical position is so active and dynamic that even within this first period of his work there is no theoretical unity. Recent works of the early period, particularly the The Spirit of Christianity [Hegel, 1907, 241-342], indicate Hegel's gradual theoretical break with Kant and shift to opposition to his moral philosophy. Hegel does not come along with the deontological and transcendental basics of Kant's ethics. He considers it to be the representation of the "spirit of Jewish slave religiosity." In contrast, he proposes the New Testament's concept of love, which overcomes the contradiction between the "tendency" and the "law.". External law-abide and authority, which Kant formally does not accept, in fact, now act from inside as the principles of his "categorical imperative." However, whether the authority and law-abide are external or internal, their essence does not change. Therefore, in Hegel's opinion, Kant's ethical doctrine holds a contradiction and the morality requires a fundamental theoretical reconsideration. The principle of this new Hegel's theoretical approach is the accentuation of the historical context of the study of philosophical problems, or in terms of "Phenomenology of Spirit", is the necessity to evaluate the result only with its development. "Nor is the result which is reached the actual whole itself; rather, the whole is the result together with the way the result comes to be." [Hegel, 1979, 4]

Correlation between the morality and religion in Phenomenology of Spirit, it still close to the Kantian. Hegel, conducting his inquiries on the historical level, still remains partly at the level of the problems of subjective awareness of own belonging to total absolute. That is why in Phenomenology of Spirit the thinker highlights the connection of subjective morality and objective religiousness. Moral consciousness still remains in the role of a "guide to religion." The central concept of moral doctrine is "duty", the dialectical development of which, gradually pushes the self-consciousness to the idea of God as the eternal perfect moral legislator. Morality and duty (its essential basis, which conciliates the relativity of sensual tendencies and necessity of moral obligation) appear as the essential conditions of selfconsciousness's consideration of its own spirituality and divinity and the same consideration about the entire Universe. In Phenomenology of Spirit, morality appears as a transitional link from alienated spirituality in determinate-being-as-such up to the "sublation" of this alienation in the absolute comprehension.

Such a model of the correlation between morality and religion in terms of content is very close to Kantian. However, Kant's and Hegel's models are not equal. In Kant's opinion, the moral consciousness is the basis of religious consciousness and leads to the idea of a God. Nevertheless, the question of the final justification of the "Practical Reason" postulates (which are the conditions of possibility of morality) still remains open. That is because Kant clearly realizes the impossibility of its rational resolve without carrying out the pure rational speculations (that have nothing in common with the reality). Kant considers such essential postulates of morality as the subjects of "Rational Belief." By doing this he demonstrates his agnostic position on this issue. Hegel, by contrast, proclaims the possibility of knowledge of God. Moral and religious consciousness in these terms appears as the necessary stages of such knowledge. Such totally-cognitive position of Hegel appears more optimistic that Kant's one. 
At the same time, Kant in the matter of justification of morality, religion and their correlation seems to be more realistic. The reason for such realism is the following: Hegel touched upon the questions of the "philosophical abyss" by proclaiming the knowledge of God, but did not overcome Kant system, as he believed. His methodology could be called a radical metaphysical turn, rehabilitation of the pre-Kantian, dogmatic method of metaphysical speculation, which still holds antinomies, pointed out by Kant.

Alternativeness of Kant's and Hegel's positions is evident. However, at the same time, it becomes clear that they both, in all their greatness, remain unilateral. It seems impossible to re-conciliate their positions. But in this case, it seems suitable to mention the lines, written by Leo Shestov that there are such philosophical questions which are risky to answer because the answer might kill the question. Enough contribution to the history of philosophy would be the fact of asking of such questions itself. The contradiction between Kant and Hegel cannot be solved without standing on a particular position. Nevertheless, their attempts to solve the problem of prove of the possibility of God's existence is highly crucial for the history of philosophy as well as Kant's doctrine of antinomies, deontological ethics, the Hegelian principle of identity between "thinking and being" and his dialectics.

Hegel's concept of the correlation between morality and religion within the Encyclopedia of the Philosophical Sciences [Hegel, 2010] fundamentally differs from the Kant's model of it. Encyclopedia of the Philosophical Sciences represents his fully formed, historical and objective point of view on morality and religion, and the general transformation of his earlier theoretical positions. Hegel's concepts of morality as a personal form of realization of the absolute and religion as self-revelation of Spirit did not transform much in comparison with Phenomenology of Spirit. However, his perspective on the correlation between these two phenomena altered essentially.

Kant's and Hegel's positions, if considered separately, reveal a certain unilateralism. Kant proved himself as an outstanding philosophical anthropologist and skilful analyst of human subjectivity. He carried out a fundamental study on morality and religion considering them as grounded in the human soul. Hegel developed the dialectic method, justified and observed the principles of deployment of the world objectively-historical and cultural reality, and provided a comprehensive assessment of the Man as the social and historical being. He considered morality and religion as the necessary stages of development of the social consciousness. He propounded the doctrine of "ethical life", as a form of human relations regulation that overcomes the controversy of morality and law themselves. Theoretical combination of productive achievements of both approaches allows him to carry out the complete philosophical evaluation of morality, religion and their correlation.

\section{Conclusions}

Several key theoretical ideas of Kant and Hegel, which can be used productively in the modern solution of the problem of correlation between morality and religion, can be consequently pointed out.

Kant's consideration of religion as "bridge" between the ideal of morality (which is possible only in a noumena world) and everyday life of a person (phenomena world) becomes relevant today. The thinker emphasizes that religion, along with the law (legality), most appropriately implement the idea of moral perfection in the phenomenal world. Presently due to a deficit of morality and the permanent search for the ways to conserve, develop and strength it, the Kant's 
consideration of religion as a medium between morality and the phenomenal world is worth to be heard.

We must outline another presently important Kant's idea. He mentioned that it is impossible to uncover the essence of humanity ("human nature") without the consideration and thorough study of the ability to believe. Kant emphasizes the ontological status of mentioned ability (in other words - religiosity) within the human soul. The evidence for such statement seems to be the general historical process. Despite all the historical theoretical and practical attempts to prove the inability of religious consciousness and worldview and eventually to destroy it, the phenomenon of religion still exists and plays an important role in the moral education and preservation of morality.

In addition, finally, the Kant's emphasis on the problems of religion and their irreconcilability to church-religion worth attention in general. The necessity for consideration and study of this experience is caused by the present Ukrainian's tendency of non-reflexive religious worship (rituals, symbols etc.)

Hegel's theoretical model of correlation between morality and religion delivers following relevant concepts. The distinction between the "positive" and "subjective" religion; consideration of phenomenon of the "folk religion"; the distinction between morality and "ethical life", which enable historical analysis of the correlation between morality and religion.

The distinction between "positive" and "subjective" religion emphasizes the necessity of a reflexive attitude to the idea of religion and its embodiment. By this statement, Hegel demonstrates his theoretical closeness to Kant's positions, continuing his critique of nonreflexive external liturgical religiosity.

The early Hegel's idea of "folk religion" is one of the most successful assertions in the history of philosophy for theoretical fundamentals of national self-identity. Such an idea presently can be used for Ukrainian national and political self-identification.

\section{References}

Aliaiev, Gennadii. Religious Foundations of Culture (The Controversy Between Simon Frank and Simon Lurie on "Vekhi”) Philosophy and Cosmology. Vol 16, 2016: 190-198.

Hegel, Georg Wilhelm Fredrich. Volksreligion und Christentum / Hegels theologische Jugendschriften: nach den Handschriften der Kgl. Bibliothek in Berlin. J.C.B. Mohr, 1907. P.1-72.

Hegel, Georg Wilhelm Fredrich. Das Leben Jesu / Hegels theologische Jugendschriften: nach den Handschriften der Kgl. Bibliothek in Berlin. J.C.B. Mohr, 1907. P. 73-136.

Hegel, Georg Wilhelm Fredrich. Die Positivität der christlichen Religion / Hegels theologische Jugendschriften: nach den Handschriften der Kgl. Bibliothek in Berlin. J.C.B. Mohr, 1907. P. 137-240.

Hegel, Georg Wilhelm Fredrich Der Geist des Christentums und sein Schicksal / Hegels theologische Jugendschriften: nach den Handschriften der Kgl. Bibliothek in Berlin. J.C.B. Mohr, 1907. P. 241-342.

Hegel, Georg Wilhelm Friedrich. Phenomenology of Spirit / Translated [from the German] by A. V. Miller. With analysis of the text and foreword by J. N. Findlay. Oxford: Clarendon Press, 1979.

Hegel, Georg Wilhelm Fredrich. The Science of Logic, Cambridge University Press, 2010, p. 609. 
Correlation between Morality and Religion in Ukrainian Society: Productive Ideas in German Idealism for Modern Consideration by Vadym Tytarenko

Hegel, Georg Wilhelm Fredrich. Encyclopedia of the Philosophical Sciences in Basic Outline. Cambridge University Press. 2010.

Kant, Immanuel. Philosophical correspondence 1759-99. Chicago University Press, 1967. P.205

Kant, Immanuel. Critique of pure reason. Cambridge University Press, 1998.

Kant, Immanuel. Critique of Practical Reason / Cambridge University Press, 2015.

Tytarenko, Vadym and Rudenko, Sergii. Kant's Studies in Ukrainian Philosophy of Soviet Period. Future Human Image, Volume 9, 2018: 107-114. 